\title{
SOCIAL INCLUSION CHALLENGES OF REFUGEES: A CASE STUDY
}

Jolanta Millere ${ }^{1}, \mathrm{PhD} /$ assistant professor; Signe Dobelniece ${ }^{2}, \mathrm{PhD} /$ associate professor 1,2Latvia University of Life Sciences and Technologies

\begin{abstract}
In recent years, as in other EU countries, the number of asylum seekers and refugees has risen steadily in Latvia. Consequently, great attention is devoted to their inclusion in society. Although there are many policy documents for inclusion policy at EU and national level and different support measures are foreseen, inclusion in the new environment is not easy. The aim of the paper is to highlight the challenges of inclusion asylum seekers and refugees face. The descriptive analysis is based on the literature review. Also an in-depth interview is used to illustrate the problems faced by a refugee family in the process of inclusion.

The paper conceptualises the terms of an asylum seeker and a refugee, gives insight into the dimensions and problems of social exclusion and inclusion, and analyses the experience of a Syrian family in case of inclusion into Latvian society. From the interview, it appears that the main problems faced by refugees are the lack of adequate financial resources, lack of awareness of their rights and legislative aspects, and insufficient Latvian language skills for adult family members. The integration of refugees into society is largely influenced by their own motivation as well as the available support.
\end{abstract}

Key words: asylum seekers, refugees, alternative status, social exclusion, social inclusion.

JEL code: 131 , I38

\section{Introduction}

Due to various political, social and economic processes in recent years, the number of immigrants in European countries, including Latvia, has increased rapidly. In 2015, 1.321.600 people have applied for EU asylum, which is almost 5 times more than in 2010 (Challenges in the Labour Market..., 2016). A similar trend can be observed in Latvia (LR IM Pilsonibas..., 2017).

For people who have lost their habitual environment, it is not easy to integrate into a new environment with different culture, language, legislation, health care, education system etc. The situation is also aggravated by psychological disturbances associated with both the situation in the previous place of residence and the transfer to a new home country. Although the policy planning documents of both the EU and Member States level provide support for the integration of asylum seekers and refugees, their inclusion in the new environment and society is fraught with many problems and challenges.

The aim of the paper is to highlight the challenges of inclusion that asylum seekers and refugees face. The following tasks are set: 1 ) to define asylum seekers and refugees; 2) to conceptualize social exclusion and social inclusion; 3 ) to identify the process of inclusion and its main problems from the viewpoint of refugees. The descriptive analysis is based on the literature review and on the publicly available statistical data. Also, an in-depth interview is used to concretise the problems faced by a refugee family in the process of inclusion.

\section{Research results and discussion}

\section{Conceptual and policy framework}

Lately, refugees and refugee crises have been talked about frequently. This concept is not always used correctly referring to all migrants. According to the 2015 Asylum Law, an asylum seeker, a refugee and an alternative status must be differentiated.

An asylum seeker is a third-country national or a stateless person who has expressed a wish to acquire refugee or alternative status at the border crossing point or when already in the territory of the Republic of Latvia (Section 1 (9), Asylum Law, 2015). Not all asylum seekers can obtain the required status, since most of them do not meet the eligibility criteria but rather are considered as economic migrants - persons who voluntarily leave their country in order to take residence 
elsewhere, mainly due to economic considerations (UNHCR, 2007). In this case, the person cannot be considered being a refugee.

A refugee is "a third-country national who on the basis of justified fear from persecution due to his or her race, religion, nationality, membership of a specific social group or his or her political views is located outside the country where he or she is a national, and is unable or due to such fear does not wish to accept the protection of the country where he or she is a national" (Section 37 (1), Asylum Law, 2015).

Alternative status is given more often than refugee status. Alternative status can be granted to "a third-country national or a stateless person who cannot be granted refugee status ..., if there is a reason to believe that he or she may be exposed to serious harm after return to the country of origin thereof and due to this reason is unable or does not wish to accept the protection of the abovementioned country" (Section 40 (1), Asylum Law, 2015).

In the last 20 years (from 1998 to July 31, 2017), only 141 of the 2418 asylum seekers have acquired refugee status, and 477 - alternative status (LR IM Pilsonibas..., 2017). The year-by-year breakdown is reflected in Table 1.

Statistics on asylum seekers, refugees, alternative status

\begin{tabular}{|c|c|c|c|}
\hline Year & $\begin{array}{c}\text { Asylum } \\
\text { seekers }\end{array}$ & Refugees & $\begin{array}{c}\text { Alternative } \\
\text { status }\end{array}$ \\
\hline $\mathbf{2 0 0 0}$ & 5 & 1 & - \\
\hline $\mathbf{2 0 0 5}$ & 20 & - & - \\
\hline $\mathbf{2 0 1 0}$ & 61 & 7 & 18 \\
\hline $\mathbf{2 0 1 1}$ & 335 & 9 & 18 \\
\hline $\mathbf{2 0 1 2}$ & 189 & 10 & 20 \\
\hline $\mathbf{2 0 1 3}$ & 185 & 14 & 21 \\
\hline $\mathbf{2 0 1 4}$ & 364 & 3 & 21 \\
\hline $\mathbf{2 0 1 5}$ & 328 & 6 & 23 \\
\hline $\mathbf{2 0 1 6}$ & 350 & 47 & 107 \\
\hline
\end{tabular}

Source: LR IM Pilsonibas un migracijas lietu parvalde, 2017

Although there are some differences between refugees and persons with an alternate status in relation to their rights, duties and support, they also have much in common, especially with their inclusion in the new environment. Therefore, this article does not differentiate between refugee and alternative status, and the term "refugees" will be applied to both categories.

Granting asylum is an international obligation, first recognised in the 1951 Geneva Convention on the Protection of Refugees. In the area of refugee integration, EU gives support to Member States in both formulation of policy planning documents and finances. Since 1999, the EU has been working to create a Common European Asylum System and improve the current legislative framework, harmonising common minimum standards for asylum. Several directives and regulations have been developed and adopted to establish high standards and stronger cooperation to ensure that asylum seekers are treated equally in an open and fair system (European Commission, 2018).

As the article does not claim to be a comprehensive and systematic analysis of policy planning documents, attention is focused on only a few of the most significant ones. One of them - the Common Basic Principles for Immigrant Integration Policy in the EU (2004) - provides for a common approach to the integration of third country nationals across the EU and sets out priority 
measures to be taken both at EU and national level and lists main integration areas: education, labour market, access to vocational training, access to basic services, active participation and social inclusion (Action Plan on the Integration..., 2016). In the context of recent refugee crisis, an important document is the European Commission's A European Agenda on Migration (2015), which includes four pillars for managing migration: 1) reducing incentives for irregular migration; 2) border management; 3) a strong common asylum policy; 4) a new policy on legal migration, where among other activities, attention is also paid to integration: "for the new programming period (2014-20), at least $20 \%$ of ESF resources will contribute to social inclusion, which includes measures for integration of migrants with a particular focus on those seeking asylum and refugees, as well as children. The funds can support targeted initiatives to improve language and professional skills, improve access to services, promote access to the labour market, inclusive education foster inter-cultural exchanges and promote awareness campaigns targeting both host communities and migrants" (A European Agenda..., 2015).

The authors of the study "Integration of Refugees in Latvia: Participation and Empowerment" argue that refugee integration in Latvia is not conceived through targeted policy documents or strategies (UNHCR, 2015). The Commission for Citizenship, Migration and Integration in its Work Report (Session of September 2015 - Spring, 2016) also points to the risks arising from the lack of unified coordination, management and oversight in the implementation of asylum policies. At present, the main planning document for integration policy in Latvia is the Guidelines for National Identity, the Civil Society and Integration Policy (2012-2018) (2012), where integration is viewed rather widely, extending not only to asylum seekers and refugees, but to several categories of people, and the goal of integration is a cohesive society.

\section{Social exclusion and inclusion}

Refugees, like all citizens, have certain needs, but their situation is different. Beyond meeting the immediate needs of refugees and asylum seekers, it is essential to promote their active integration in society, as they experience high risk of social exclusion. Social exclusion is a complex, multidimensional process that manifests itself as a complete or partial marginalization of individuals, households or groups. Reasons for social exclusion are diverse: poverty, unemployment, inadequate education, and discrimination. They can overlap and be at the same time both the causes of social exclusion and its consequences. Social exclusion can manifest itself in a number of spheres of life or dimensions. This aspect of social exclusion has been focused on by several researchers. For example, Levitas emphasizes the limited participation in consumption, savings, production, political and social activities (Pantazis, Gordon, Levitas, 2006). Silver highlights three dimensions of social exclusion with several sub-dimensions:

- resources: material and economic; access to services; social resources;

- participation: economic; social; cultural and educational; political and civic;

- quality of life and wellbeing: health; living environment; crime and criminogenic situation (Silver, 2015).

In turn, Kronauer believes that "there is a far-reaching agreement on the central dimensions in which social exclusion manifests itself, regardless of the variations in conceptualization and realization of the studies: exclusion from the labour market, economic exclusion, cultural exclusion, exclusion by social isolation, spatial exclusion, institutional exclusion" (Kronauer, 1998). 
Social inclusion is the opposite process, which aims to provide the necessary resources, services and opportunities to ensure individuals' full participation in different spheres of society.

Integration of asylum seekers and refugees does not have one universal definition, and a number of thematic studies use the definition of the UNHCR, in which integration is understood as the end product of a dynamic, multi-faced two-way process with three interrelated dimensions: a legal, economic and socio-cultural dimension. Integration requires efforts by all parties concerned, including preparedness on the part of refugees to adapt to the host society without having to forego their own cultural identity, and a corresponding readiness on the part of host communities and public institutions to welcome refugees and to meet the needs of a diverse population (UNHCR, 2015; Grooteman, 2016).

Although policy planning documents and legislation ensure support for the integration of asylum seekers and refugees into society, this does not guarantee that they will be fully protected from social exclusion and will not face problems and obstacles in a complex and often long process of integration. Previous studies show that challenges are possible in all dimensions of social exclusion. The main problems are related to: the field of law - insufficient knowledge of their rights and the possibilities to defend them; housing - affordability, discrimination from landlords and reluctance to rent out; employment - insufficient institutional support, problems with recognition of previous education and qualifications, discriminatory attitude of employers; financial difficulties - insufficient financial support from the state and municipalities, inability to find work and earn an adequate salary; education and schooling - educational disruption, communication barriers, little teachers' experience in a multicultural environment, difficulties in accessing higher education, racism, discrimination; health care-access to services is hampered by disadvantaged attitudes, poor medical personnel awareness of refugees and their needs, poor awareness of entitlements; social isolation - separation from and lack of contacts with family members in the home country, and restricted contacts with larger community; mental health issues due to trauma, including survivor's guilt (Agenda for Integration, 2004; UNHCR, 2015; Settlement Challenges...; Petijums par patveruma..., 2011). All of the abovementioned problems are exacerbated by insufficient knowledge of the local language, the acquisition of which also involves challenges. According to research "Integration of refugees in Latvia" (UNHCR, 2015) results, there is no centralized Latvian language training system in Latvia, there is a lack of information about the courses; the acquisition of language is also hindered by the course fee; the lack of tailor-made training programs to cope successfully with a different level of knowledge in the group; lack of opportunities to acquire the highest level of knowledge, lack of English language proficiency in Latvian language teachers.

However, refugee integration experiences may vary, not all of them experience all the above mentioned problems. As the research shows, the extent to which refugees are integrated into society depends on a number of factors, for example, on paid employment opportunities at the place of a new residence, information provided by individuals about their rights and the possibilities to receive state and local government support, as well as refugees' motivation to stay in the country of asylum.

\section{Insights into the inclusion of the Syrian family}

A study was conducted in December 2017, in which a family of migrants from Syria was interviewed. The family has been living in Latvia since April 2017. There are two adults and four children in the family. The family was given an alternative status, and all members of the family 
are slowly integrating into the community. In the context of alternative status, the family has been granted a residence permit for only a year, which gives them a sense of insecurity about the future and opportunities to stay in Latvia.

All children are included in the education system and receive education according to their age and ability. The youngest daughter ( 5 years old) attends a pre-school educational institution, the middle daughter ( 14 years old) acquires elementary education, but the two eldest (17 years old) acquire a profession in a vocational education institution. According to parents, all teachers are very sympathetic and good: "...yes, everything is fine, teachers are very good, kids are eager to go to school... ". From the beginning, everyone was worried about the success at school, since the four years spent avoiding war in Turkey and Greece; children were not allowed to get an education. The daughter, who studies at the Craft School as a hairdresser, has friends and feels good at school: "I have some problems because of the Latvian language, but I get help and teachers are very understanding..." Also, the son is satisfied with his choice of school and profession: "I study at the Craft School as a cook and I really like school, I have a lot of friends...".

All members of the family understand Latvian language; however, it is still hard for them to express themselves in Latvian. The eldest son and daughter who are 17 years old are fluent in English and at times when Latvian language causes difficulties; they use their English language skills. Three of the eldest children are involved in a youth organization (they weren't able to tell its name), where they meet other young people, learn more about the city, and have the opportunity to learn languages. They learned about the possibility to take part in an organization at the Association "Asylum "Safe house"". The language barrier is the biggest problem for the mother because she does not have a job yet, and she uses her native Arabic at home.

The father, working at the Caramel Workshop, is satisfied with his work: "I like work, and the attitude of the superior is good ... everything is fine." However, the family is concerned about their financial situation, because the father earns 500 euros per month and until April the family will still receive state support of 600 euros, but then their financial situation is at risk because the mother has health problems, which makes it impossible to start a paid employment right now. Persons who have acquired alternative status have the right to receive benefits for a period of seven months within a 12-month period from the date of granting the status. Monthly payments for housing and other payments amount to 300 euros; the father believes that it will not be possible to survive on the remaining 200 euros per month: "...we do not know what will happen after the state financial support no longer will be given ... Children have to study, my wife still cannot work ... how are we going to manage financially?" By profession, both parents are cooks who love their profession and are very proud of their craftsmanship. Mother would like to work in a confectioner's room. The biggest problem in the financial area for the family is that they are denied the right to buy goods on credit. For example, a family would like to equip its dwelling with furniture, buy a television set, but it cannot be done because financial resources are insufficient, nor can they get a credit because of the alternative status.

All family members already consider Latvia as their home and would like to stay here: "...we like everything here - nature, city, people, but most of all - the market (everyone is laughing)".

In regard to the culture, the family does not see big problems. They are glad that in Latvia they can buy all the necessary spices and products for the preparation of their national dishes. The family love baking their national sweets, which are usually enjoyed during the holidays. However, celebrating of holidays and following the traditions are hindered by the residence that is not yet 
arranged in the traditional fashion. The father believes: "...during holidays the family must get together; everyone should talk and share, and the environment is extremely important...". Father also believes that the family needs a large sofa, where the whole family could sit and relax together: "..we have a good home, four rooms and a kitchen, but there is no sofa, where we all could sit; and there is no TV. It is also rather cold in our home, only sixteen degrees, I would like it to be warmer... ".

They don't have any issues with the health care either: " .. my wife spent two weeks in hospital because of an operation, and we didn't have to pay anything... Our family doctor also is very good."

However, in regard of being well-informed, there are some shortcomings, for example, the family believes that the hospital was paid by the "Asylum "Safe House"'", rather than from the state budget. The father also mentions some disadvantages: "I would like to understand what taxes I have to pay, how much and whether I have the preferences for children - I do not know anything; I earn 2.50 euro per working hour and that's all I know...".

The family has received the most support from the "Asylum "Safe House""' association. Within the association, the family has its own trust person who informs them about the opportunities and necessary activities in the area of integration. The association's representative is happy with the family and believes that her support has been essential in all aspects of their life - she helped to find a job, schools for the children with school and housing.

Emotionally, the family is strong; they support each other and believe that they will do their utmost to arrange their life and start fully living in Latvia as soon as possible. The family is very proud of the fact that while living in Mucenieki they were already convinced they would stay in Latvia; they were the only ones living in Mucenieki who wanted to stay in Latvia rather than emigrate to another country. The biggest wish of the family is to acquire Latvian citizenship and become a part of its society

\section{Conclusions, proposals, recommendations}

1) The number of asylum seekers and refugees has increased in recent years in EU countries, including Latvia. If in 2000 five people asked for asylum in Latvia, then in 2016 there were already 350 asylum seekers. Accordingly, the number of refugees and persons with alternative status has also significantly increased.

2) The countries that have joined the 1951 Geneva Convention on the Protection of Refugees are obliged to host asylum seekers and refugees. In order to make their integration process more successful, the EU has placed great emphasis on developing policy planning documents, has adopted a number of Directives and Regulations, and provides financial support to the Member States. The main integration policy planning document in Latvia is Guidelines for National Identity, Civil Society and Integration Policy (2012-2018). However, despite the documents developed and accepted and the support planned and provided, the integration of refugees into society is associated with many problems.

3) It is clear from the empirical study that the integration of refugees into society is largely influenced by their motivation to stay in the country and efforts to tackle their problems as well as the support provided by the state, local governments, NGOs and the community.

4) The fact that alternative status is granted only for a year creates a sense of insecurity in people regarding future opportunities that reduce their integration opportunities in society. 
5) The main problems faced by refugees are the lack of financial resources that prevent them from settling their daily lives according to the family needs; insufficient awareness of their rights and legislative aspects that are directly related to their daily lives, for example in the field of tax policy, as well as the lack of Latvian language skills, especially for adult family members.

\section{Bibliography}

1. Action Plan on the Integration of Third Country Nationals. 2016. European Commission, Brussels. Retrieved: https://ec.europa.eu/home-affairs/sites/homeaffairs/files/what-we-do/policies/european-agendamigration/proposal-implementation-package/docs/20160607/communication_action_plan_integration_thirdcountry_nationals_en.pdf. Access: 5.01.2018.

2. A European Agenda on Migration. 2015. European Commission, Brussels. Retrieved: https://ec.europa.eu/antitrafficking/sites/antitrafficking/files/communication_on_the_european_agenda_on_migration_en.pdf. Access: 05.01.2018.

3. Agenda for Integration. 2004. The Refugee Council. Retrieved: https://www.refugeecouncil.org.uk/assets/0001/6370/agenda_integ_nov04.pdf. Access: 14.01.2018.

4. Asylum Law. 2015. Retrieved: https://likumi.lv/ta/id/278986-patveruma-likums. Access: 05.01.2018.

5. Challenges in the Labour Market Integration of Asylum Seekers and Refugees. 2016. Ed. by Arora, L., Besic, A., Hawley-Woodall, J., Hayward, L., Manoudi, A., Santos-Brien, R., Scott, D. European Employment Policy. Observatory Synthesis. Directorate-General for Employment, Social Affairs and Inclusion; European Employment Policy Observatory. Retrieved:

file://C:/Documents \%20and \%20Settings/Lietotajs/My \%20Documents/Downloads/EEPO \%20Refugees \% 20Synthesis \%20report \%20EMPL_FINAL \%20(2).pdf. Access: 10.01.2018.

6. European Commission. 2018. Common European Asylum system. Retrieved: https://ec.europa.eu/homeaffairs/what-we-do/policies/asylum_en. Access: 05.01.2018.

7. Guidelines on National Identity, Civil Society and Integration Policy of the Republic of Latvia for the period from 2012 to 2018. Riga, 2012. Retrieved:

https://www.km.gov.Iv/uploads/ckeditor/files/Sabiedribas_integracija/Petijumi/En_Pamatnostad.pdf. Access: 17.01.2018.

8. Kronauer, M. 1998. 'Social Exclusion' and 'Underclass' - New Concepts for the Analysis of Poverty. Hans-Jürgen Andreß (ed.). Empirical Poverty Research in a Comparative Perspective. Aldershot: Ashgate. Pp. 51-71. Retrieved: http://eswf.uni-koeln.de/mitarbeiter/andress/poverty.htm. Access: 17.03.2017.

9. LR IM Pilsonibas un migracijas lietu parvalde. 2017. Statistika patveruma joma. Retrieved: http://www.pmlp.gov.lv/lv/sakums/statistika/patveruma-mekletaji.html. Access: 05.01.2018.

10. Pantazis, C., Gordon, D. and Levitas, R. 2006. Poverty and Social Exclusion in Britain, Bristol, The Policy Press.

11. Petijums par patveruma mekletaju, beglu un personu, kuram pieskirts alternativais statuss, piekluvi izglitibai Latvija. 2011. Latvijas Cilvektiesibu centrs. Retrieved: http://providus.Iv/article_files/848/original/Gala_zinojums_ped2.pdf?1326198814. Access: 05.01.2018.

12. Settlement Challenges. Retrieved: http://www.roads-to-refuge.com.au/settlement/settlementchallenges.html. Access: 04.01.2018.

13. Silver, H. 2015. The Contexts of Social Inclusion. DESA Working Paper No. 144. Retrieved: http://www.un.org/esa/desa/papers/2015/wp144_2015.pdf. Access: 12.01.2018.

14. UNHCR. 2007. Refugee Protection and International Migration. Retrieved: http://www.unhcr.org/4a24ef0ca2.pdf. Access: 12.01.2018.

15. UNCHR. 2015. Integration of Refugees in Latvia. Participation and Empowerment. Retrieved: http://www.emn.Iv/wp-content/uploads/UNHCR_Integration-of-refugees-in-Latvia.pdf. Access: 28.12.2017.

16. The Common Basic Principles for Immigrant Integration Policy in the EU. 2004. Retrieved: http://www.eesc.europa.eu/resources/docs/common-basic-principles_en.pdf. Access: 12.01.2018. 